\title{
Ethics and professional orientation of Serbian journalists
}

\author{
Verica Rupar ${ }^{1}$
}

Auckland University of Technology, School of Communication Studies, New Zealand

\author{
Sonja Seizova ${ }^{2}$
}

University of Belgrade, Serbia

\section{doi:10.5937/comman12-14541}

Abstract: Studies of ethical orientations of journalists, based on large-scale surveys of professional norms and values, generate data that are an important indicator of journalism culture. While it is true that what journalists say they do is not always the same as what they actually do, the discourse about professional roles and ethical standards is a prominent marker of journalistic culture and an element that can be and is usually compared cross-nationally (Hanitzch \& Vos, 2016). This study of Serbian journalists follows this stream of scholarship, offering an empirical contribution to the discussion about journalists and their professional orientation. Based on the survey conducted in 2014 as a part of the Worlds of Journalism Study, we first present a socio-demographic profile of Serbian journalists, and then focus on the views on the role of journalists in society, perceived influences on their everyday work and journalists perception of ethics. The study approaches journalism as a field of cultural production and adopts the community structure model (Tichenor, Donohue \& Olien, 1980) to explore the link between professional orientations of journalists and the demographic characteristics of the community news media are based in. It tests the idea that the perception of the journalist's role in society might be different in smaller, relatively homogenous towns than in larger, more demographically diverse cities. The study found Serbian journalism culture to be ambiguous, related to the complex set of interactions with political and economic fields, and based on the tension between different models of journalism that have historically influenced the development of the profession in the region, "interventionist" and "monitorial".

Keywords: ethics, journalism, professional roles, autonomy, political culture, community structure

\footnotetext{
1 Contact with author: verica.rupar@aut.ac.nz.

2 Contact with author: s.seizova@gmail.com.
} 


\section{Introduction}

Discussion about journalism ethics usually starts with the examination of the codes that define professional values and outlines the way practice should be conducted. A closer look at the Serbian Journalists' Code of Ethics is no exception; it articulates the standards at which the professional ought to operate. As such it is a valuable source of information that supports comparison of Serbian journalism ethics with the standards elsewhere. One of the first comparative studies of codes of ethics around the world (Jones, 1980) showed that a distinction could be made between universal journalistic values of integrity, truth and objectivity and specific national modalities linked to the level of freedoms and political, legal and economic differences between the countries. Journalists do not work alone, nor do they produce stories in a vacuum. Although they are not explicitly governed by the state, publisher, or advertisers - at least not in democratic societies - they are considered to be working in relation to, and under the influence of, all of those factors. The factors which impact on journalists' work are individual characteristics of specific news workers, their routines of work, organizational-level concerns, institutional issues, and larger social systems (Shoemaker \& Reese, 2014). A hierarchy of influences model underlines the semi-autonomous character of the journalistic field - an independence in telling the stories as they really are, but within the boundaries between journalistic and other fields of political, social and cultural production. In the light of this interdependence of journalism, a code of ethics is a welcome and valuable source of information because it articulates the professional commitments of journalism itself. However, where these commitments are coming from, what they depend on and how they relate to the content produced requires a more detailed line of inquiry regarding journalists and their moral decisions.

In this study, we approach journalism and journalism ethics from the field theory point of view (Bourdieu, 2005), adopting the community structure model (Tichenor, Donohue \& Olien 1980; Rupar 2014) to address the question of how journalists' professional orientations relate to the demographic characteristics of community in which journalists employ their craft. The study of Serbian journalists and their professional values tests the idea that the perception of the journalist's role in society might be different in a relatively homogenous community than in a more demographically diverse one. We first present a brief overview of the socio-demographic profile of Serbian journalists, then 
focus on their views on the role of journalism in society, perceived influences on everyday work and their ethical orientation. The following research questions are addressed:

- How do Serbian journalists define their role in society?

- What is the perceived influence on journalistic work?

- What are the ethical orientations of Serbian journalists?

- Who do they trust?

We look at these results comparing the north and south of the country and three cities: Subotica (diverse community), Belgrade (diverse metropolis) and Kragujevac (relatively homogenous community). We put forward an argument that Serbian journalism culture is still underdetermined and multiplied, influenced by community structure and shaped by the tension between the different models of journalism that co-exist within the same culture.

\section{Theoretical framework}

Reporters around the world talk about their profession in terms of serving the public interest. With no hesitation they apply strict utilitarian justifications, while also regularly aspiring to Kantian absolutes. This intriguing ethical paradox (Plaisance et al., 2012) is often explained by the contradictory nature of the journalistic field. The relations within the newsroom; those between journalists, editors, the advertising department and publishers, function as a network that shapes a journalist's individual actions. The journalist's position as an agent that serves public interest - to stay with the most commonly used description of the importance of journalistic work - is dynamic, "being aimed either at conserving or transforming the structure of relations of forces that is constitutive of the field" (Bourdieu, 2005: 30). The sphere of action is also limited, because it interacts with other spheres of cultural production and, at the same time, develops "distinctive forms of practice, conceptions of (their) social role, and standards for judging cultural production and assigning status to cultural producers" (Hallin, 2005: 230). The interaction between journalistic and other fields, however, does not function in the same way everywhere and the intensity of interactions differ across the globe. 
Hallin and Mancini's (2004) model of media systems, suggests that a good starting point for the investigation of the relationship between the media (and journalism) and society is the identification of the development of media markets (with emphasis on mass circulation press), political parallelism (or the degree and nature of the links between the media and political parties), the development of professionalism in journalism and the degree and nature of state intervention in the political system. The authors used these criteria to evaluate different media systems across the globe and came up with three distinctive models: 'democratic corporatist', 'polarized pluralist' and 'liberal'. The 'democratic corporatist model' (the media system in northern continental Europe) is characterized by the historical coexistence of commercial media and media tied to organized social and political groups and by the relatively active but legally limited role of the state. The 'polarized pluralist model' (Mediterranean countries of southern Europe) demonstrates the integration of the media into party politics, a weaker historical development of commercial media, and the strong role of the state. And the 'liberal model' (Britain, Ireland, the US and Canada) is characterized by the relative dominance of market mechanisms and of the commercial media (Hallin \& Mancini, 2004: 21). These models of media systems are sometimes used as a ground for discussing distinct associated journalism cultures, but with different success.

Journalism culture in post-communist countries has been looked at as a variation of Southern European, polarized pluralism model (Dobek-Ostrowska \& Glowacki, 2008), or most recently as transitional journalism (Andresen et al., 2017) but efforts to find a single label for essentially diverse societies always bring a risk of oversight. While the journalistic field as "the site of actions and reactions performed by social agents endowed with permanent dispositions, partly acquired in their experience of the social fields" (Bourdieu, 2005: 30) situates the profession in relation to the world, and through the process of socialization shapes the views of its agents, there is still relative autonomy of the field and its agents in relation to this institutional setting. In that sense, it is possible to be idealistic and pragmatic, utilitarian and aspiring to moral absolutes, because journalistic norms of accuracy, fairness, balance and objectivity are perceived to overcome the singularity of 'right' and 'wrong' decisions. Unpacking the application of professional norms in the news texts demonstrates how it works. The study of the influence of the objectivity norm on public discussion about 
contested issues (Rupar, 2007) for example shows that journalism's strong belief in objectivity entails a triple A: Approach, Account and Attitude. While objectivity takes recognizable form in the case of approach (finding sources, ensuring two sides of a story, conducting fact checking ad verification, namely methods of journalistic work) and attitudes (editorial policies, norms, values, codes of ethics, mission statements), it is the account of reality (news stories themselves) that reveals the context-dependent nature of journalistic work.

Distinction between journalistic approach, account and attitude is an important point because the survey of Serbian journalists whose results we are about to present deals with their perception and views of their roles in society, what they think they do and want to do, not what they actually do. Knowing that "imposition of a definition of the world is in itself an act of mobilization which tends to confirm or transform power relations" (Bourdieu, 2005: 39), we examine the relationship between journalists' views on their profession and the community they are based in. Researchers found that the constantly changing political, economic, and social environment of the post-communist region stands behind the lack of professional identity among Central and East European journalists (Mancini \& Zielonka, 2012). Journalism's ambition to contribute to the development of democracy in the East European context is more than an element of professional ideology. Embedded in the political, legal and social context, it is linked to political culture, which stands as a space of interaction between cultural (journalism included) and political fields.

The concept of political culture serves here as an explanatory theme. It is defined as a relatively coherent cluster of attitudes, values, feelings and information skills that give meaning and justification to actions (Topf, 1989: 52) passed on through the process of socialization. This set of orientations is fundamental for economic and political performance (Jackman \& Miller, 1996: 636). In politically turbulent regions, the process of socialization is frequently interrupted and develops primarily outside the institutions. The absence of political continuity and the non-institutional nature of the process of socialization, leave a trace on journalism as a meaning-making cultural practice. The idea of 'common good', one of the most important concepts in democratic societies, struggles to reach the shores of societies such as Serbia. Some scholars argue lack of clear idea of the common good is one of the key elements of the regional political culture (Stamenova, 2005) and it sheds light on the context in which region- 
al journalism operates. Using a Western understanding of the 'common good' as "the welfare of all citizens, rather than that of factions or special interests" (Glasser, 1999: 68) to explain the East European ideas of individual and the group is an impossible task, as Lauk (2009) rightly points out when discussing the applicability of Western media models in the East European context. In her comparative analysis of Balkan political culture, Stamenova (2005) explains how the vagueness of the 'common good' idea in the Balkans stands in sharp contrast to the Western understanding of communal attachments. Western understandings of the common good are developed around the notion that

"our sense of identity is inseparable from our awareness of ourselves as members of a particular family or class or community or people or nation, as bearers of a specific history, as citizens of a particular republic; and that we look to participation in the political realm as a way in which we can develop and refine our sense of ourselves by developing and refining [?] form of community with which we can be proud to identify." (Rawls, cited in Clifford, 1999: 70)

It is the community that we take into consideration in this paper. Academic research on journalism and community focuses primarily on emerging forms of community journalism (for example Meadows et al., 2009) while studies of the news media and community structure focus on media representation of social issues (Dunwoody \& Griffin, 1993). The community structure model suggests that more pluralistic and diversified communities tend to work in an atmosphere where conflict is a more routine part of public life and as such is reported in news media. By comparison, smaller communities prefer consensus, and news media in those communities play the roles of legitimizers and builders of that consensus. This model has been used to confirm that community pluralism (structural stands for demographic diversity) plays a role in the way media cover conflictive social issues: the media frames are driven by community structures and, by interpretation, championed by the prevailing power structure of a town. The media frame events and issues of public concern, reacting either as promoters of change or watchdogs of society. What drives this choice of a practice has remained less explored. This is an oversight because the socialization process every journalist is exposed to involves not only wider ideological assumptions coming from political and economic structures, or the organiza- 
tional structure of a newsroom, but the evolving value system coming from the community they belong to. How does it work in the case of Serbian journalists?

Previous studies of Serbian journalists and their capacity to respond to social, economic and technological challenges revealed that average journalist works long hours, is irregularly paid, and fears the future (Milivojević, 2012). Journalism in Serbia is "slow in mobilizing resources to address professional challenges" (Milivojević, 2012: 285). In the last survey, Serbian journalists were asked to name the biggest problems the profession is faced with. They listed low salaries (20.36\%), low level of professionalism and - more specifically - not enough respect for journalism ethics $(16.78 \%)$, and professional reputation and status (16.09\%). When it comes to ethics only $1.92 \%$ think journalists know very well the ethical principles of the profession, with the majority admitting they do not follow the principles (Milivojević, 2012). Professionalism, measured by IREX Media Sustainability Index (2017), was at a lower level in 2017 than in 2001 (1.25 and 1.43 respectively, on the scale $0-4$ ). Following the initial sharp improvement in the early 2000s, the overall MSI for all five measured dimensions is on a downward trajectory in particular after 2008: from 1.86 to around 2.5 in 2006, and 1.78 in 2017 (Cetinić, 2017), placing Serbia's media system among the Unsustainable Mixed Systems.

The study positions these results within the context of the semi-autonomous nature of the journalistic field, the absence of political continuity in the region, the Balkan's political culture that lacks mechanisms for articulation of the common good and Serbia's slow process of transition to democracy.

\section{Methodology}

This study is part of the Worlds of Journalism Study (WJS) ${ }^{3}$, a collaborative project based on a common methodological framework conducted in 67 countries in the period 2012-2016 . It is based on a survey of Serbian journalists conducted in early 2014 on a sample of 407 journalists purposively chosen based on quota (media type, content, reach, ownership), with the newsroom size taken into account, and on convenience when faced with a low response rate in some of the planned media. The fieldwork was carried out by face-to-

\footnotetext{
3 This research was supported by the Worlds of Journalism Study Central Funding grant (2013).

4 The full "Serbian Journalists" country report is available on the Worlds of Journalism Study website (https://epub. ub.uni-muenchen.de/31033/1/Country_report_Serbia.pdf).
} 
face, telephone, on-line, and e-mail interviews, using a fully structured and standardized questionnaire.

For the purpose of this study, a person was considered a professional journalist or photo-journalist if at least half of their income was coming from producing and editing news media content, or supervising and coordinating editorial processes. The number of journalists in the country was estimated at 8,000 , based on the 2011 census and membership in three journalists' associations - Association of Journalists of Serbia (UNS), Independent Association of Journalists of Serbia (NUNS), and Independent Association of Vojvodina Journalists (NDNV). A total of 82 media outlets which produced their own content were included in the sample.

In the year 2011 the highly saturated media market comprised of: 1,050 registered media outlets, out of which 591 print (around 25-30 dailies, 94 weeklies, 43 biweeklies, 224 monthlies), 107 on-line media, three news agencies and 10-20 other type of wires. There were $134 \mathrm{TV}$ stations with broadcasting licenses ( 6 national, 30 regional, 98 local), and 321 radio stations with valid licenses (5 national, 1 provincial/regional, 48 regional, and 267 local), while 47 radio-stations and 9 TV stations operated without a license.

The full questionnaire had 23 questions (the full questionnaire can be accessed here: http://www.worldsofjournalism.org/research/2012-2016-study/ methodological-documentation/).

To investigate the relationship between journalism ethics and community structure we focus on questions related to journalism roles, influences on their work, ethical orientations and political trust (questions C12-C16 and O4-5).

This set of data is then compared regionally. We compare journalists' views on roles, influences and ethics in three cities: the capital Belgrade, Subotica in the north, and Kragujevac in the south. Given the asymmetric geographical distribution of media outlets in Serbia ${ }^{5}$ strongly favouring the capital, findings from sub-samples in Subotica (north) and Kragujevac (south) are also checked against their corresponding regions which share similar features: more diverse Serbia North, comprising Autonomous Province of Vojvodina north of Belgrade, and more homogenous Serbia South, south of the capital.

5 Cities: Belgrade: $\mathrm{N}=278$; Subotica $\mathrm{N}=13$; Kragujevac $\mathrm{N}=13$.

Regions: Belgrade N=278; Serbia North $N=61$; Serbia South N=67. 
Table 1: Diversity indicators*

\begin{tabular}{|c|c|c|c|c|c|c|c|}
\hline & & Serbia & Belgrade & Subotica & Kragujevac & $\begin{array}{l}\text { Serbia } \\
\text { North }\end{array}$ & $\begin{array}{l}\text { Serbia } \\
\text { South }\end{array}$ \\
\hline \multirow{2}{*}{ Population } & $\mathrm{N}$ & $7,186,862$ & $1,659,440$ & 141,554 & 179,417 & $1,931,809$ & $3,595,613$ \\
\hline & $\%$ & 100 & 23.09 & 1.96 & 2.49 & 26.89 & 50.03 \\
\hline \multirow{2}{*}{$\begin{array}{l}\text { GDP per } \\
\text { capita** }^{* *}\end{array}$} & in RSD & 548,000 & 904,000 & 429,000 & 427,000 & 563,000 & 369,000 \\
\hline & $\begin{array}{l}\%, \\
\text { Serbia }=100\end{array}$ & 100 & 165 & 78 & 78 & 103 & 67 \\
\hline \multirow{6}{*}{ Ethnicity \% } & Serbs & 83.32 & 89.9 & 29.86 & 95.9 & 66.75 & 88.8 \\
\hline & Hungarians & 3.53 & 0.1 & 32.66 & 0.02 & 13 & 0.03 \\
\hline & Bosniaks & 2.02 & 0.1 & 0.15 & 0.02 & 0.04 & 3.97 \\
\hline & Roma & 2.05 & 0.1 & 2.09 & 0.82 & 2.19 & 1.18 \\
\hline & Croats & 0.8 & 0.46 & 9.18 & 0.1 & 2.43 & 0.08 \\
\hline & Bunjevci & 0.2 & 0.01 & 8.74 & 0.002 & 0.85 & 0.002 \\
\hline \multirow{3}{*}{ Religion \% } & Orthodox & 84.59 & 88.89 & 27.78 & 95.5 & 70.25 & 90.3 \\
\hline & Catholic & 4.96 & 0.82 & 57.59 & 0.18 & 17.42 & 0.18 \\
\hline & Muslim & 3.1 & 1.92 & 1.94 & 0.37 & 0.73 & 4.91 \\
\hline Education*** & $\begin{array}{l}\text { BA and } \\
\text { higher }\end{array}$ & 10.59 & 19.6 & 8.9 & 11.37 & 8.05 & 7.16 \\
\hline Unemployment & $\%$ & 22.43 & 17.87 & 21.51 & 28.29 & 22.72 & 24.52 \\
\hline $\begin{array}{l}\text { Computer } \\
\text { literacy*** }\end{array}$ & $\%$ & 34.21 & 48.05 & 37.24 & 37.79 & 34.9 & 27.42 \\
\hline
\end{tabular}

\section{* Source: 2011 Census}

** Source: $\underline{\text { http://webrzs.stat.gov.rs/WebSite/repository/documents/00/02/45/36/RD98-RBDP2015.pdf }}$

*** Older than 15 years;

*** Internet access and households with PCs: 65\%, ranging from 46\%-95\%, depending on income category.

Table 1 shows similarities in size, GDP per capita and computer literacy between Subotica and Kragujevac, while the most notable difference is in ethnic composition and religious affiliation: in very diverse Subotica no ethnic group comprises more than one third of population (Hungarians, Serbs) and no confession claims more than $60 \%$ of believers (Christian Catholic, followed 
by Christian Orthodox). Kragujevac is, to the contrary, 95\% ethnically and religiously homogenous, with dominant Serb ethnic identity and Christian Orthodox religion. Their corresponding regions share the same characteristics, albeit to a lesser extent: the North has two-thirds majority Serbian population and $70 \%$ of Orthodox believers, as compared to the South with $88 \%$ of Serbian ethnic majority and 90\% Orthodox confession.

The unemployment rate is higher in Kragujevac (28.29\%) and in the South $(24.52 \%)$ than in Subotica $(21.51 \%)$ and the North $(22.72 \%)$, while the education level is similar (around 8\%) in all but Kragujevac (11.37\%), lower than the country average (10.59), and much lower than in the capital Belgrade (19.6\%). Relatively higher level of bachelor degree owners in Kragujevac can be attributed to the significantly more industrial orientation of the city, and the existence of a university there since 1976.

Belgrade and the North have GDP per capita above the country level by $65 \%$ and $3 \%$ respectively, while the South is the poorest with $33 \%$ below the country GDP, confirming the uneven regional development and dominance of the capital, which also accounts for nearly one quarter of the country's population.

The ethnic composition of the sample reflects the level of diversity of the corresponding population. ${ }^{6}$

Following Dunwoody \& Griffin (1993) methodology and based on listed demographic data, Subotica and Belgrade are considered to be diverse communities: Subotica in terms of ethnicity and religion and Belgrade in terms of computer literacy, unemployment, income, educational structure, while Kragujevac stands for a more homogeneous society according to census data. We also look at Belgrade as a capital city and Subotica and Kragujevac as regional cities.

\subsection{Profile of respondents ${ }^{7}$}

A representative journalist in Serbia is in her early forties, with a university diploma in journalism or communication. Their average age was 40.92 years, ranging from 21 to 74 years $(s=10.47)$, of which they spent an average of 15.99

\footnotetext{
${ }^{6}$ It is interesting to note that ethnically diverse Subotica and the North also have the highest proportion of respondents who didn't respond to the question about their ethnic identity.

The following sections are based on the results of the second wave of the Worlds of Journalism Study, as presented in the Country Report (2016).
} 
years in journalism $(s=9.64)$, spanning across 54 years. In terms of education, 68.1\% of journalists said they held university degree or higher: 59.7 percent held a Bachelor's Degree or equivalent, 16.6 percent had some university studies but no degree, 14.9 percent had completed high school, 7.9 percent had a Master's degree or equivalent, and 1 percent had a $\mathrm{PhD}$. Of all the senior editorial and managerial staff with a diploma (around 70\%), 53.21\% specialized in journalism or communications. Of those with a degree, $62.5 \%$ are female and $37.5 \%$ are male.

In terms of political orientation, half of the respondents position themselves left of center $(51.1 \%), 23.3 \%$ at center, and one-quarter right of center.

For $52.2 \%$ religion is of no or little importance. Nearly one-third feel no religious affiliation, $64.5 \%$ are Orthodox Christians, 3.2\% Roman Catholics, and $2.8 \%$ Muslim. When it comes to ethnicity, 22.4\% refused to declare. Of the rest, $89.2 \%$ are of Serbian ethnicity, 3.5 of Hungarian, 2.8\% declare themselves as Yugoslavs, $1.6 \%$ as Bosniaks, $0.9 \%$ as Montenegrins, $0.6 \%$ as Albanians, and as much as Romanian, and $0.3 \%$ each as Croatian and Ukrainian.

The majority of journalists interviewed in Serbia were employed full-time (91.2\%), whereas 6.1 percent were freelancers, and 2.5 percent had part-time jobs. Less than half $(43.0 \%)$ said they were members of professional associations. They produced or worked on an average of 27 stories per week, ranging from one to $54(s=45.4)$.

The respondents were predominantly generalists, with 64.6 percent covering various topics and subjects, and around one third reporting on a specific beat (35.4\%): $20.2 \%$ on hard news, and $13.6 \%$ on soft news. Hard news specialists are more likely to be female than male $(69.2 \%)$, to have specialization in journalism or communications (56.25\%), and to be a rank-and-file journalist $(61.25 \%)$. Female journalists are more than two times predominant over their male colleagues in news/current affairs, politics and economy (40 and 15 respectively), and clearly prevail in culture beats. Male journalists prevail in covering sports and, to an extent, in entertainment.

In terms of media ownership, two-thirds of journalists surveyed in the study $(65.8 \%)$ worked in private news organisations, $21.6 \%$ in public service, $5.4 \%$ state-run, and $7.1 \%$ in a news organisation with mixed ownership. There were (31.7\%) journalists working for TV, $24.1 \%$ for daily newspapers, $15.5 \%$ for ra- 
dio, $8.1 \%$ for weeklies and as much for online outlets of offline media, $7.1 \%$ for news agencies, $4.7 \%$ for magazines, and $0.7 \%$ for stand-alone online outlets.

Half of the interviewed were rank-and-file journalists $(24.1 \%$ news writers and $24.1 \%$ reporters), $24.8 \%$ were senior editors, $10.3 \%$ managing editors and $8.6 \%$ editors-in-chief, while $4.9 \%$ were department heads. Producers, desk heads or assignment editors and trainees were represented by around $1 \%$ each. There were almost two times more female senior editors than male, while the difference was not that strong among news writers (55 and 42 respectively). The only position showing clear prevalence of male journalists is editor-in-chief (21 and 14 respectively).

The journalists feel that they have a reasonable level of freedom in selecting their stories (mean 3.80 on the scale 1-5, s=1.00), and they feel that they have even more freedom in selecting aspects of their stories (mean 3.94, $s=1.014$ ); $55 \%$ of them always or very often participate in editorial coordination, while $23.4 \%$ rarely or never (mean 3.5 on the scale of $1-5$ ).

\section{Results}

\subsection{What is the role of journalists in society?}

Stances about the role of journalism in society were examined by posing two questions. The open-ended one offered journalists the chance to identify cognitive roles as they see them, while the second question asked them to rate the importance of 21 journalistic roles on a scale of 1-5 (unimportant to very important). Asked what should be the three most important roles of journalists in Serbia, our respondents prioritized informative (256 responses), engaging (207) and interpretative (103) roles. Nearly half of the respondents (175) highlighted the need for the informing journalism to be objective, and 50 referred to serving the public interest. Figure 1 shows how they prioritized 21 offered journalistic roles in the answers to the second question. 
Figure 1: Journalists' roles

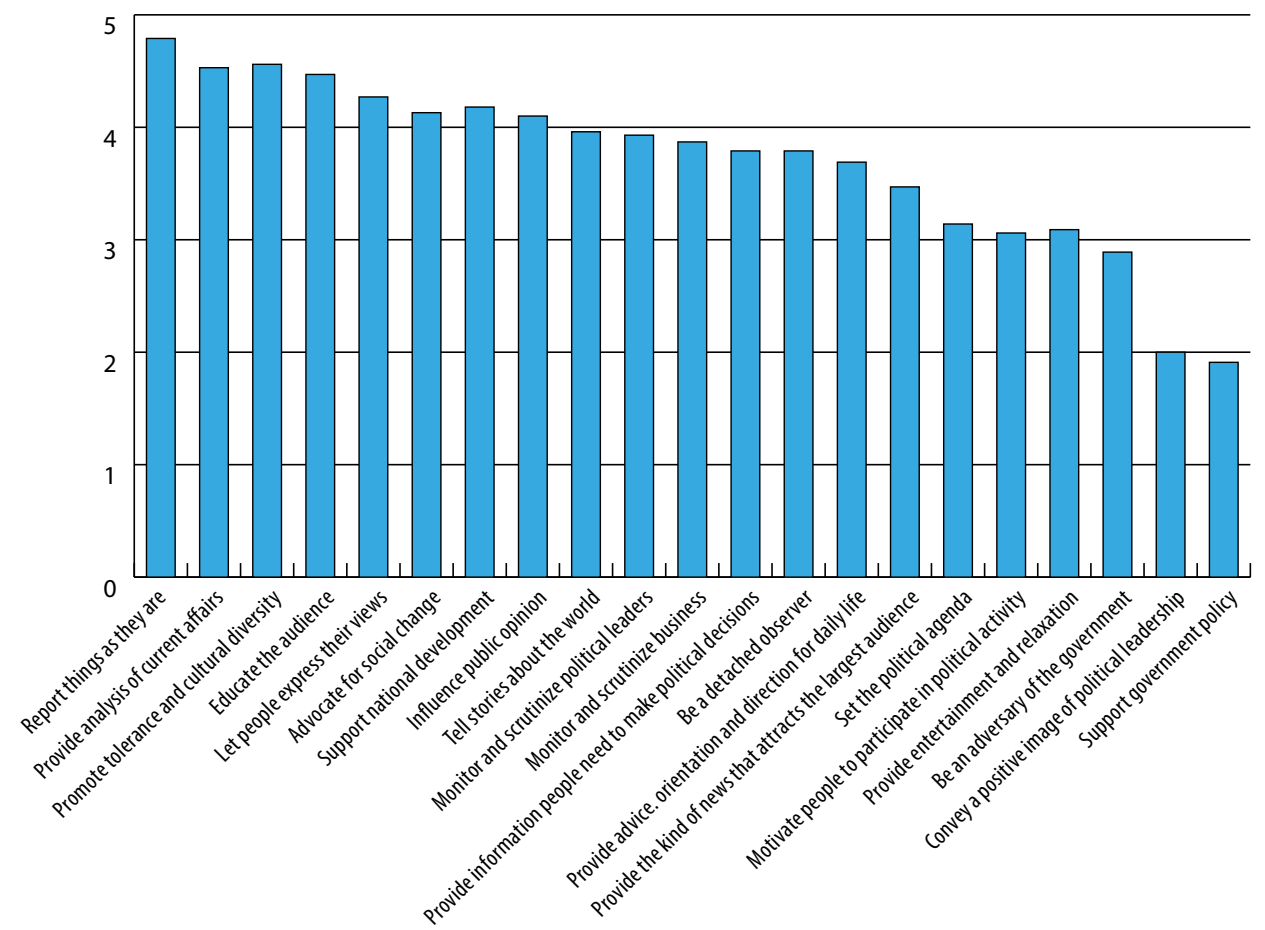

Serbian journalists perceive the most important aspects of their work to be: to report things as they are, provide analysis of current affairs, promote tolerance and cultural diversity, and educate the audience. The least important roles, scoring around or below the neutral mid-point (3) largely relate to the political arena: support government policy, convey a positive image of political leadership, be an adversary of the government, and motivate people to participate in political activity. Below the mean score (3.69) are also: provide entertainment and relaxation, provide the kind of news that attracts the largest audience, and set the political agenda. The engaging aspects of journalistic roles populate the middle of the list: let people express their views, advocate for social change, support national development, and influence public opinion. Being a detached observer is almost as important as monitoring and scrutinizing political leaders, but not very high on the list.

For the needs of the international comparison, the WJS team has aggregated journalistic roles in four dimensions by averaging the scores across indicators 
that belong to the same dimension: monitorial, interventionist, collaborative and accommodative. Figure 2 below shows that journalists in Serbia identify their role in the society primarily as interventionist, i.e. they take "a more active, socially committed and assertive role in their reporting, and in so doing they involve themselves in social and political processes to the extent that they become participants" (Hanitzsch, Hanusch \& Lauerer, 2014: 3) ${ }^{8}$, but the monitorial role is not far behind that.

Figure 2: Dimensions of roles

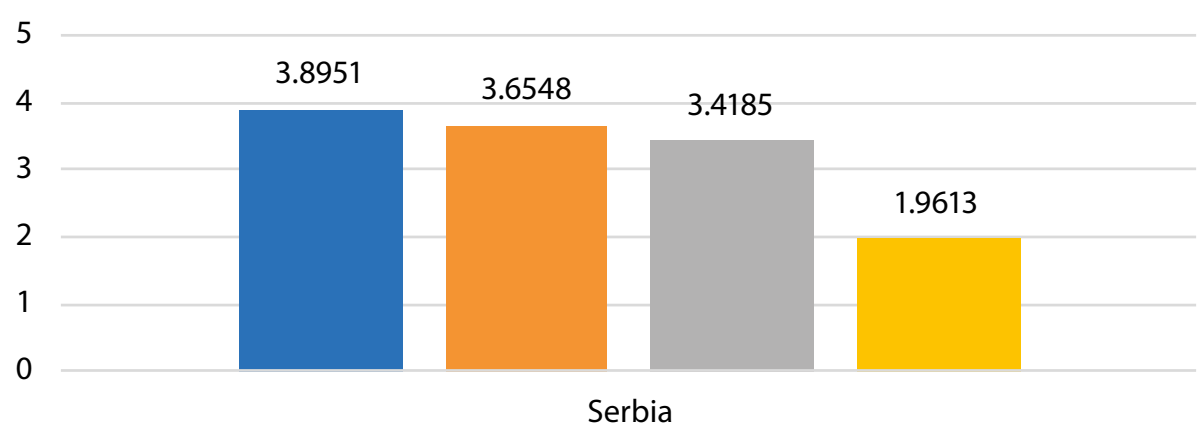

INTERVENTIONIST: Advocate for social change; Influence public opinion; Set the political agenda; Support national development

MONITORIAL: Provide political information; Monitor and scrutinize politics; Monitor and scrutinize business; Motivate people to participate in politics

ACCOMODATIVE: Provide entertainment and relaxation; Provide news that attract largest audience; Provide advice, orientation and direction for daily life

COLLABORATIVE: Support government policy; Convey a positive image of political leaders

\subsection{Ethical orientation}

Journalists were asked to state to what extent they agree with certain attitudes towards what is ethical in journalism, on a scale from 1-5 (least to most). Nearly 95 percent of the respondents agree that journalists should always adhere to their professional code of ethics, while only 13.3 percent said it was acceptable to set aside moral standards if extraordinary circumstances require it. Between the two

\footnotetext{
8 A tendency towards interventionist values was found among journalists from developing societies and transitional democracies http://worldsofjournalism.org/fileadmin/Illustration/Maps/Int_Role_Centered.png
} 
extremes, there was less agreement over situational ethics $(34.8 \%)$ and personal judgment (28.9\%).

Journalists were also asked to say to what extent they consider 12 reporting practices ethical, on a scale from always justified, justified on occasion, never justified (1-3 respectively). Figure 3 shows that the least justifiable reporting practices are altering or fabricating quotes from sources, accepting money from sources, publishing stories with unverified content, making use of personal documents without permission, and altering photographs.

Figure 3: Ethics in reporting practices

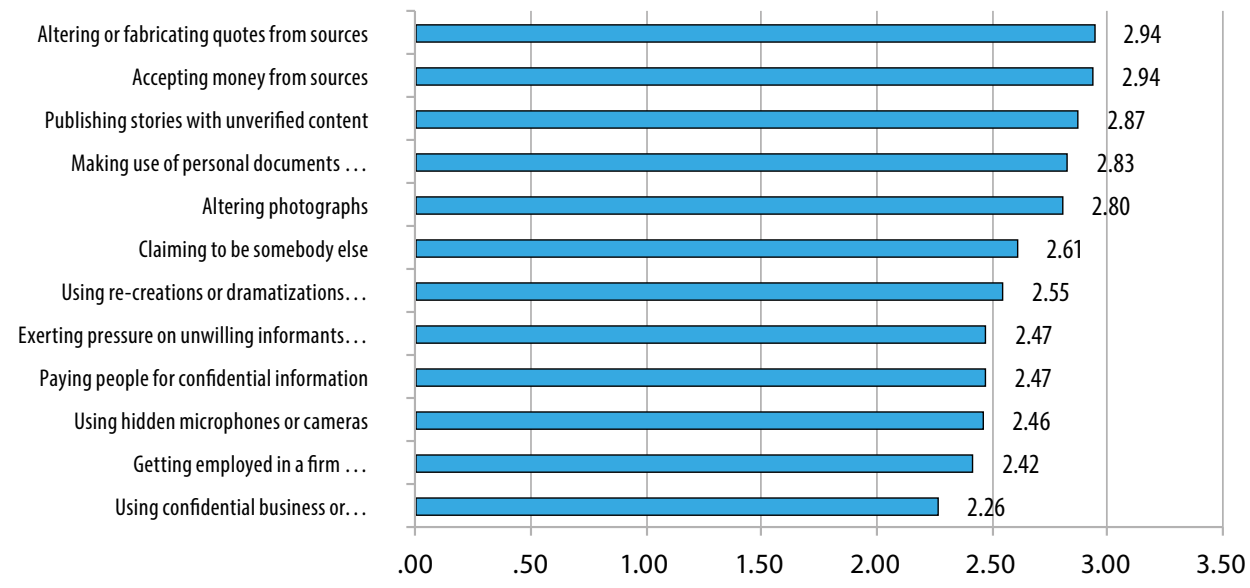

\subsection{Influences on journalists}

The overall pattern of perceived influences on journalism confirms global trends according to which influences experienced in daily professional life, such as procedural and to various degrees economic and organizational, are perceived as stronger, while political and business influences are mediated and as such perceived as weaker (Hanitzsch et al., 2010).

Journalists were asked to respond to how influential they find certain aspects of their work, on a scale from 1-5 (from extremely influential to not influential). As presented on Figure 4, journalists believe that professional ethics and personal values and beliefs have the strongest impact on their work, followed by influences stemming from personal, organizational and economic environments. The five weakest perceived influences of the 27 offered are po- 
litical: pressure groups, the military, police and state security, business people, government officials, and politicians.

The impact of economic influences features in the second third by priority the journalists attribute to it: audience research and feedback, profit expectations, advertising considerations, competing media.

Of personal networks, concentrated in the bottom third, peers of the staff, religious considerations are followed by influence from colleagues in other media, and finally by friends and family.

\section{Figure 4: Influences on journalism}

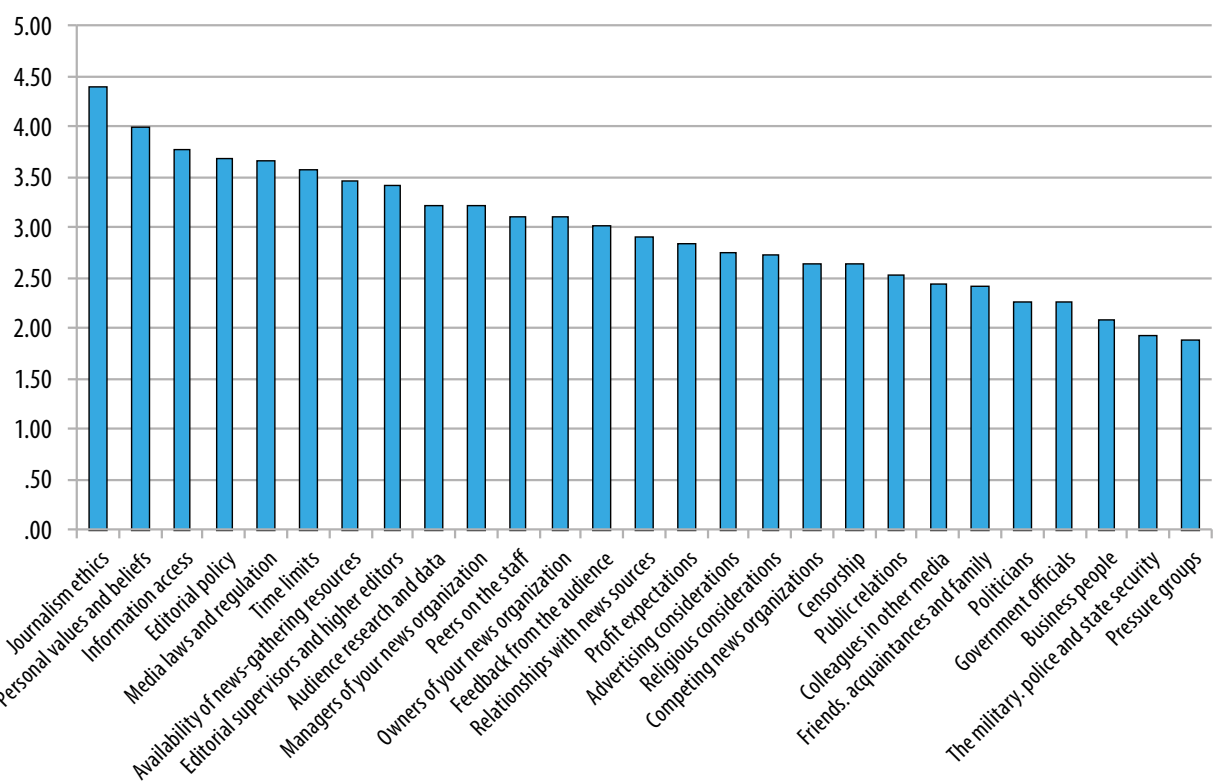

For the needs of the international comparison, the WJS team has aggregated influences on journalists in five dimensions by averaging the scores across indicators that belong to the same dimension. Figure 5 shows that the perception of journalists in Serbia concerning the influences on their work follows the global pattern established in earlier research (Hanitzsch \& Mellado, 2011): Procedural factors are perceived to have the strongest influence on journalism, followed by organizational, economic, personal, and political. ${ }^{9}$

\footnotetext{
9 For global distribution of perceived influences, see the maps: http://test.worldsofjournalism.org/1/
} 
Figure 5: Influences combined

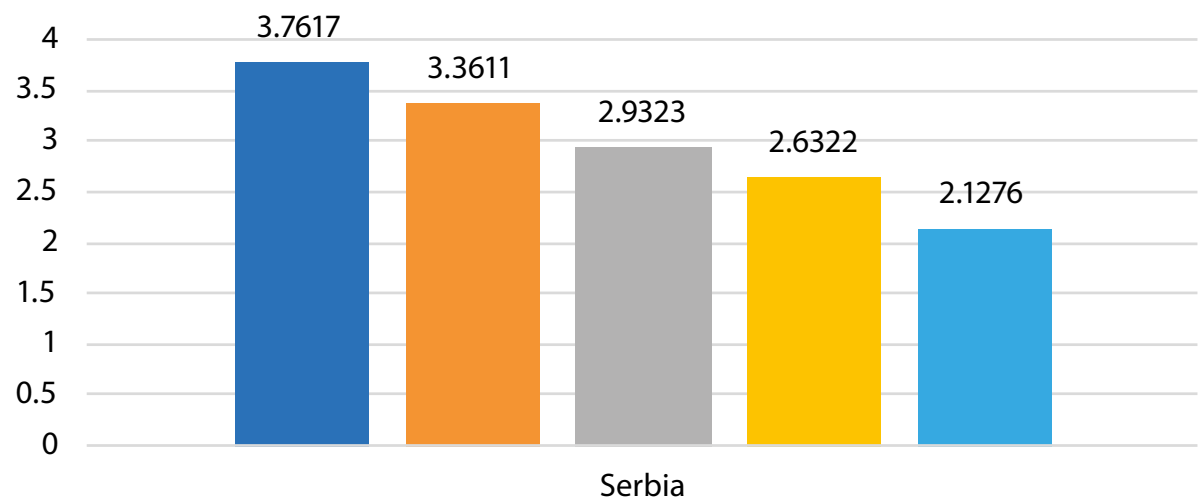

PROCEDURAL: Information access; Journalism ethics; Media laws and regulation; Available news-gathering resources; Time limits

ORGANIZATIONAL: Managers of news organization; Supervisors and higher editors; Owners of news organization; Editorial policy

ECONOMIC: Profit expectations; Advertising considerations; Audience research and data

PERSONAL NETWORKS: Friends, acquaintances, family; Colleagues in other media; Peers on the staff

POLITICAL: Politicians; Government officials; Pressure groups; Business representatives

\subsection{Trust}

On a scale from 1 to 5, the overall level of journalists' political trust in institutions remained below the mid-point, barely exceeding 2.1. As shown on Figure 6, the most trusted is the military (2.69), followed by the news media (2.65) and the police (2.40). The most distrusted are politicians in general, political parties, trade unions and religious leaders. The parliament, the government and the judiciary are in the middle, awarded 2.26, 2.17, and 2.08 points. 
Figure 6: Journalists' trust in institutions

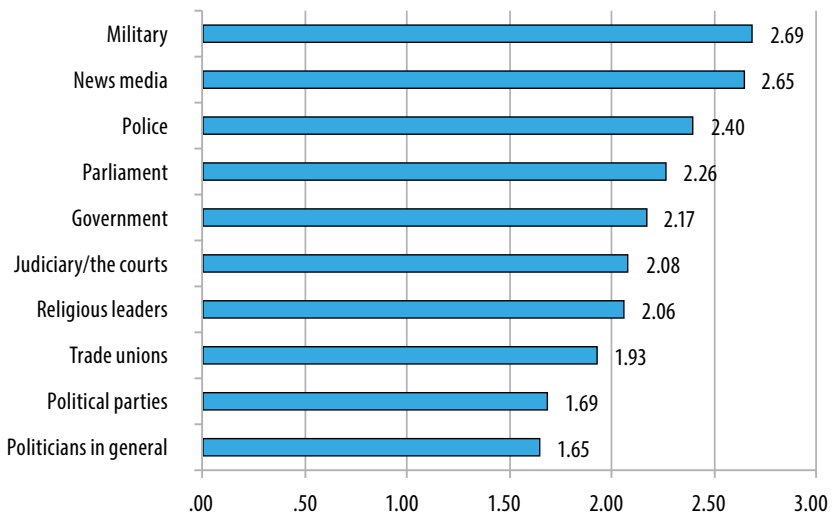

Low trust in institutions is confirmed by journalists' low social trust, with $87.5 \%$ saying that one cannot be too careful when it comes to trusting people, and $57.1 \%$ believing that most people would try to take advantage of others.

Political trust of journalists in Serbia is among the lowest globally ${ }^{10}$, in the same group with other new European democracies and some Latin American countries. Generally speaking, this is characteristic of the countries which are undergoing disruptive changes, and in which journalists tend to prioritize an interventionist role ${ }^{11}$, which in the case of Serbian journalists, goes hand in hand with the monitoring role.

\subsection{How it relates to community structure?}

How do these responses vary depending on demographic diversity of the city and region? We compared responses in Subotica, Kragujevac and Belgrade and results for the North and the South of country. In all three cities the most important journalistic role is to inform and report on things as they are, followed by educational and engaging roles, the aspects of which in many cases do not fluctuate between cities for more than two positions out of 21 offered. The least important roles are those supporting government policy and conveying a positive image of political leadership, but the level of agreement on this varies,

\footnotetext{
${ }^{10}$ For global map of differences in political trust, please see http://worldsofjournalism.org/fileadmin/Illustration/ Maps/Pol-Trust.png

${ }^{11}$ For global map of distribution of interventionist role, see http://worldsofjournalism.org/fileadmin/Illustration/ Maps/Int_Role_Centered.png
} 
with Subotica most divided (St. Dev. 1.467) on the latter and Kragujevac (St. Dev. 0.947) the least divided.

A closer look into aspects of the monitorial role and interventionist role reveals some differences and contradictions between the cities, and confirms that journalists position themselves in a continuum between the ideal-type role dimensions.

The high-diversity Subotica highly values support to national development, ranking it third (mean 4.69, St. Dev. .480). The same journalistic role is placed four positions lower and with less agreement by Belgrade (St. Dev. 1.242), and even lower by Kragujevac (9th, St. Dev. 1.256).

For Belgrade and Kragujevac, promotion of tolerance and cultural diversity is the second most important journalistic role, while in Subotica it is fourth. The two provincial cities both consider advocating for social change a relatively important role, placed fourth, but with less agreement in Kragujevac (St. Dev 1.166) than in Subotica (St. Dev. 0.66). The dynamics of political life and advantageous position of the capital appear to influence lower placement of this role in Belgrade (9th, St. Dev. 1.160).

Monitoring and scrutinizing political leaders is equally, albeit not very important in Belgrade and Subotica, ranked 10th, with controversy over the issue higher in the capital (St. Dev 1.246) than in Subotica (St. Dev. 0.953). More homogenous Kragujevac displays a tendency for a more collaborative ${ }^{12}$ journalistic role, ranking monitoring and scrutinizing political leaders 13 th out of 21 offered options. At the same time and in an apparent contradiction with this, being an adversary of the government is more important for respondents in Kragujevac (16th, St. Dev 1.32) than for those in Subotica (18th, St. Dev. 1.144) and Belgrade (19th, 1.409), where the respondents are also more divided over the issue.

Being a detached observer resonates stronger with journalists in the capital than with those in the two provincial cities. Belgrade journalists also value setting the political agenda higher (16th) than Kragujevac (18th) and Subotica (20th). Relatively high standard deviation in all three cities $(1.425 ; 1.337$; 1.231 respectively) indicates that this remains an issue of considerable contro-

\footnotetext{
${ }^{12}$ From the upcoming WJS book, Chapter 7 on Roles: "four general role dimensions in their work: monitorial, collaborative, interventionist, and accommodative roles."
} 
versy. For all three cities, conveying a positive image of political leadership and supporting government policy are the two least desirable journalistic roles.

Educating the audience features among the top five journalistic roles in all three cities. However, they differ to some extent when it comes to providing relaxation and entertainment: this is least important for journalists in Kragujevac, followed by Belgrade, while Subotica respondents place it six positions higher. Similarly, providing information for daily life is most important in Subotica (8th), followed by Kragujevac (10th) and Belgrade (14th).

The results indicate different attitudes between the three cities in several dimensions of journalistic roles:

- Ambivalent stance regarding scrutinizing political leaders and challenging the authorities; Belgrade and Subotica (diverse cities) give a preference to monitoring leaders.

- Preference in provincial cities with less dynamic development for advocating for social change, while journalists in Belgrade stress more often a notion of detached observer.

- The capital leads in seeing a journalist's role as setting the political agenda, although there is an overall reluctance towards this role.

- High reluctance towards explicit support to the authorities and their policy is consistent with global findings.

Closer look at the community level allowed us to identify some differences in significance attributed to certain aspects of journalistic roles which may get lost when the results are aggregated on regional or national levels. Results on national levels and for corresponding regions are very consistent among themselves and do not corroborate directly the differences identified in the cities. The findings from the regions clearly confirm that outside of the capital setting the political agenda is perceived as the less important journalistic role.

When it comes to monitoring and scrutinizing political leaders, the South catches up with Subotica, Belgrade and Serbia, ranking it 10th by importance, while the North overall considers it less important than Subotica (13th and 10th respectively).

If compared with the four composite roles indexes (Figure 7), Belgrade aligns with Serbia, prioritizing the same roles: interventionist (mean 3.8508), monitorial (3.6561), accommodative (3.2518), and collaborative (1.7674), but 
with somewhat less strong support for the accommodative and collaborative roles. Kragujevac and the South follow the same pattern, while journalists in Subotica and the North prioritize accommodative over the monitorial role, i.e. they put more weight on addressing the audience members as consumers and on providing orientation for everyday life.

Figure 7: Roles in comparative perspective

Subotica

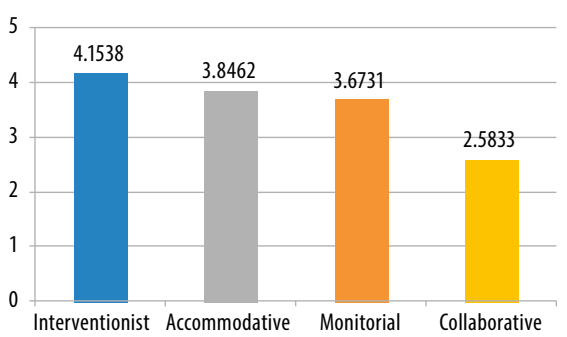

S. North

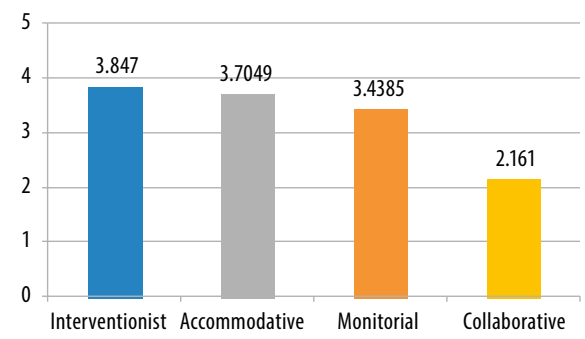

Kragujevac

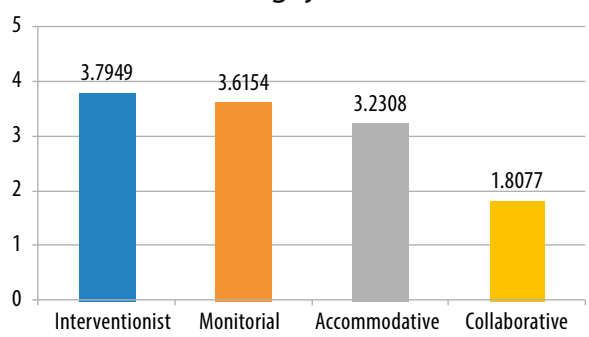

S. South

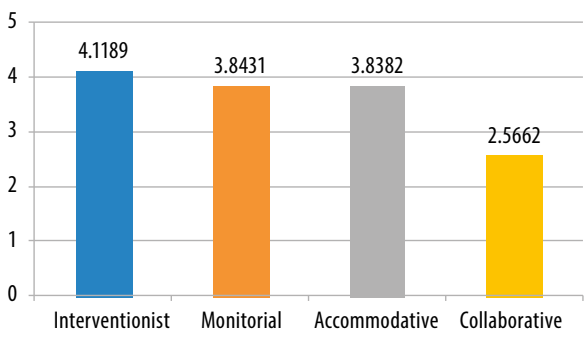

Respondents in the three cities prioritize in the same way their beliefs about what is ethical in journalism. The difference between the cities is in the extent to which they agree, with overall lower standard deviation in more homogeneous Kragujevac, and considerably lower mean in that city for situational ethics and personal judgement, both scoring the same (1.85, as compared to 3.33 in Subotica and 2.57 in Belgrade for situational). This level of ambivalence is reflected in the findings for the corresponding region, the South, where respondents placed personal judgement higher than situational ethics and display relatively high disagreement on all but the absolute ethics. Serbia, the North, Belgrade and Subotica align in prioritization of ethical stances, with some fluctuations in mean scores.

When it comes to what is ethical reporting, journalists in the three cities displayed rather consolidated beliefs about what they find always, occasionally, 
and never justified (scale 1-3 respectively), with standard deviation fluctuating around 0.5 , and ranking of reporting practices varying by one to two places on the list of 12 offered (Table 2a, b, c). The two notable exceptions are altering photographs and exerting pressure on unwilling informants to get a story.

Respondents in Belgrade consider altering photographs relatively acceptable, ranking it fifth least justifiable reporting practice, and the same attitude is reflected on the national level. However, altering or fabricating quotes from sources is ranked the most unjustifiable in Belgrade and second in Subotica and Kragujevac, after altering photographs. The two regions are more approving of altering photographs, ranking it fourth least justifiable reporting practice.

Respondents in Subotica absolutely disapprove of altering photographs and altering or fabricating quotes from sources (Mean 3, St. Dev. 0.00), and they find exerting pressure on unwilling informants to get a story the third least justifiable practice. Exerting pressure is perceived as more acceptable in Belgrade, Kragujevac, on the country and on the regional level, where it is placed 8th least justifiable reporting practice.

Journalists in all three cities believe that paying people for confidential information, getting employed in a firm or organization to gain inside information, and using confidential business or government documents without authorization are the most justifiable. The same prioritization is to some extent reflected on the regional and national levels.

Table 2a: Ethical reporting: Belgrade

\begin{tabular}{|l|c|c|}
\hline Belgrade & Mean & Std. Deviation \\
\hline Altering, fabricating quotes from sources & 2.95 & 0.264 \\
\hline Accepting money from sources & 2.95 & 0.285 \\
\hline Publishing stories with unverified content & 2.89 & 0.344 \\
\hline $\begin{array}{l}\text { Making use of personal documents (letters, pictures) } \\
\text { without permission }\end{array}$ & 2.83 & 0.387 \\
\hline Altering photographs & 2.8 & 0.445 \\
\hline Claiming to be somebody else & 2.58 & 0.544 \\
\hline Using re-creations or dramatizations of news by actors & 2.5 & 0.635 \\
\hline
\end{tabular}




\begin{tabular}{|l|c|c|}
\hline Belgrade & Mean & Std. Deviation \\
\hline Using hidden microphones or cameras & 2.43 & 0.598 \\
\hline Exerting pressure on unwilling informants to get a story & 2.4 & 0.679 \\
\hline Paying people for confidential information & 2.39 & 0.614 \\
\hline $\begin{array}{l}\text { Getting employed in a firm or organization to gain inside } \\
\text { information }\end{array}$ & 2.34 & 0.659 \\
\hline $\begin{array}{l}\text { Using confidential business or government documents } \\
\text { without authorization }\end{array}$ & 2.19 & 0.631 \\
\hline
\end{tabular}

Table 2b: Ethical reporting: Subotica

\begin{tabular}{|l|c|c|}
\hline Subotica & Mean & Std. Deviation \\
\hline Altering photographs & 3 & 0 \\
\hline Altering, fabricating quotes from sources & 3 & 0 \\
\hline Exerting pressure on unwilling informants to get a story & 2.92 & 0.289 \\
\hline Accepting money from sources & 2.92 & 0.289 \\
\hline $\begin{array}{l}\text { Making use of personal documents (letters, pictures) } \\
\text { without permission }\end{array}$ & 2.85 & 0.376 \\
\hline Publishing stories with unverified content & 2.85 & 0.376 \\
\hline Claiming to be somebody else & 2.83 & 0.389 \\
\hline Using re-creations or dramatizations of news by actors & 2.75 & 0.452 \\
\hline Using hidden microphones or cameras & 2.67 & 0.492 \\
\hline $\begin{array}{l}\text { Using confidential business or government documents } \\
\text { without authorization }\end{array}$ & 2.67 & 0.492 \\
\hline $\begin{array}{l}\text { Getting employed in a firm or organization to gain inside } \\
\text { information }\end{array}$ & 2.58 & 2.58 \\
\hline Paying people for confidential information & 0.515 \\
\hline
\end{tabular}


Table 2c: Ethical reporting: Kragujevac

\begin{tabular}{|l|c|c|}
\hline Kragujevac & Mean & Std. Deviation \\
\hline Altering photographs & 2.85 & 0.555 \\
\hline Altering or fabricating quotes from sources & 2.85 & 0.555 \\
\hline Accepting money from sources & 2.85 & 0.555 \\
\hline Publishing stories with unverified content & 2.77 & 0.599 \\
\hline $\begin{array}{l}\text { Making use of personal documents (letters, pictures) with- } \\
\text { out permission }\end{array}$ & 2.69 & 0.63 \\
\hline Using re-creations or dramatizations of news by actors & 2.54 & 0.776 \\
\hline Using hidden microphones or cameras & 2.54 & 0.66 \\
\hline Exerting pressure on unwilling informants to get a story & 2.46 & 0.66 \\
\hline Claiming to be somebody else & 2.46 & 0.66 \\
\hline Paying people for confidential information & 2.46 & 0.66 \\
\hline $\begin{array}{l}\text { Getting employed in a firm or organization to gain inside } \\
\text { information }\end{array}$ & 2.38 & 0.768 \\
\hline $\begin{array}{l}\text { Using confidential business or government documents } \\
\text { without authorization }\end{array}$ & 2.15 & 0.689 \\
\hline
\end{tabular}

The overall pattern of prioritization of the 27 offered influences is consistent with the global WJS findings.

Journalists in all three cities perceive six aspects of political influences on their work as the weakest, with slight fluctuations in ranking: pressure groups, business people, the military, police and state security, politicians, government officials, and censorship.

On the other hand, ethics and personal values and beliefs are the two strongest influences in all three cities, followed in small cities Subotica and Kragujevac by influences stemming from personal, organizational and economic environments.

In homogeneous Kragujevac, religious considerations are ranked at the high 6th place, compared to 19th in Belgrade and 23th in Subotica.

Characteristic for the capital is that the first third of the list is occupied by procedural and organizational dimensions of influences, while personal net- 
works tend to concentrate in the bottom third, just above political influences (which could be attributed to more complex organization of bigger newsrooms, and more impersonal professional relations).

Of personal networks, peers on the staff is ranked in Subotica much higher (7th) than it is in Belgrade (12th) and Kragujevac (13th). Colleagues in other media have less influence in all three cities, ranked 19-20th just above friends and family.

Overall, journalists in Serbia are rather consistent in their perception of influences with global prioritizing of composite indexes, or dimensions of influences on journalistic work. Figure 8 shows that only in Subotica organizational influences are perceived as slightly higher than economic.

Figure 8: Perception of influences

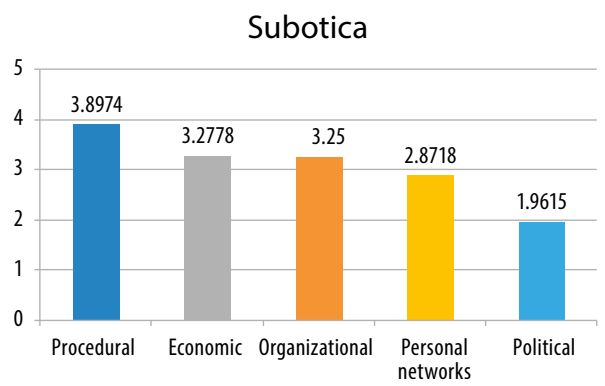

S. North

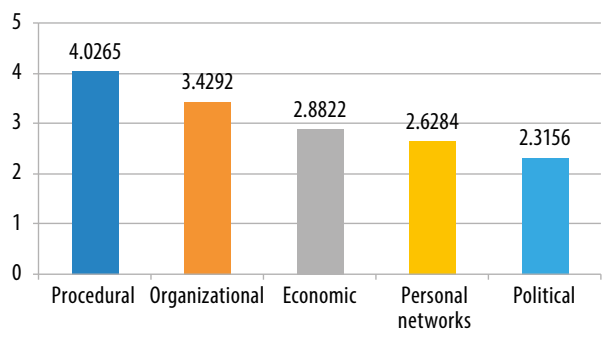

Kragujevac

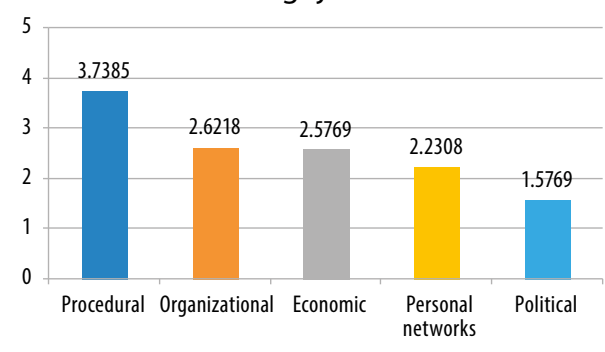

S. South

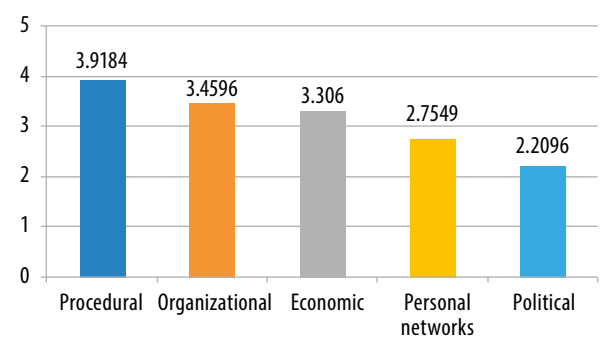

Journalists in the three cities differ in regards to the level of trust they award political institutions: on the scale from 1-5, the overall level of trust in Kragujevac is on the level of the country score (2.1), journalists in the high-diversity Subotica are the most trusting (2.7), and those in the capital the least (1.9). 
While Belgrade and Kragujevac mostly align with the prioritization of trust awarded to institutions on the country level, Subotica again diverges in several aspects. In all three cities the military tops the list as the most trusted institution, but with notably a high score of 3.75 in Subotica, as compared to 2.5 in Belgrade and 3 in Kragujevac. News media, second in Belgrade and Kragujevac, rank 5th in Subotica, the parliament and the government are somewhat better placed than in the other two cities (3rd and 4th, as opposed to 4th and 5th respectively), while religious leaders belong to the second least trusted category. Journalists in Kragujevac confirm their perception of relatively high influences of religious considerations on their work by placing trust in religious leaders higher than their colleagues in Belgrade and Subotica - as sixth out of ten offered institutions. The most distrusted in all three cities are politicians in general, the same as on the national level. When it comes to social trust, journalists in Subotica trust people less than those in Belgrade and Kragujevac (91.7, 87.6 and 84.6 respectively), and believe more strongly that most people would try to take advantage of others (58.3, 56.1 and 53.8).

\section{Table 3: Trust in institutions}

\begin{tabular}{|c|c|c|c|c|c|}
\hline Belgrade & Mean & Subotica & Mean & Kragujevac & Mean \\
\hline Military & 2.50 & Military & 3.75 & Military & 3.00 \\
\hline News media & 2.48 & Police & 3.58 & News media & 2.92 \\
\hline Police & 2.26 & Parliament & 2.83 & Police & 2.69 \\
\hline Parliament & 2.09 & Government & 2.83 & Government & 2.23 \\
\hline Government & 1.96 & News media & 2.62 & Parliament & 2.08 \\
\hline Judiciary/the courts & 1.91 & Judiciary/the courts & 2.62 & Religious leaders & 1.85 \\
\hline Religious leaders & 1.87 & Trade unions & 2.42 & Judiciary/the courts & 1.77 \\
\hline Trade unions & 1.73 & Political parties & 2.25 & Trade unions & 1.62 \\
\hline Political parties & 1.57 & Religious leaders & 2.18 & Politicians in general & 1.46 \\
\hline Politicians in general & 1.54 & Politicians in general & 1.92 & Political parties & 1.46 \\
\hline
\end{tabular}




\section{Conclusions}

The aim of this paper has been to present empirical data on the Serbian journalists' perception of their professional roles, influences on their work, trust and the views on specific norms of professional ethics that underpin journalism practice. Using the Worlds of Journalism Study's framework of conceptualizing professional role orientations we generated data for exploring elements of Serbian journalism culture. We further examined the link between journalists' views and the demographic characteristics of community media by testing the idea that the perception of a journalist's role in society might be different in smaller, relatively homogenous towns then in larger and more demographically diverse cities.

Journalists' professional orientations are coming from the societal, organizational, cultural and individual levels simultaneously (Hanitzsch et al., 2014). They require looking at professional views as discourse, rather than a simple list of norms professionals aim to adhere to. That discourse is formed and negotiated within Serbian political culture distinguished by collectivism and egalitarianism (Popović-Obradović, 2007), and within an overcrowded and oversaturated media market (Freedom House, 2016), political discontinuity and the tension between different models of journalism that have historically influenced the development of the profession in the region. Serbian journalism culture is still to be defined, in relation to the regional and European cultures and globally too. As Örnebring points out, it might be possible that "Central and Eastern Europe will form its own distinct journalism culture/media system" (Örnebring, 2009: 8). Journalism culture in post-communist countries has been seen as a variation of the Southern European, polarized pluralism model (Dobek-Ostrowska \& Glowacki, 2008), or most recently as transitional journalism (Andresen et al., 2017) but efforts to find a single label for essentially diverse societies brings some oversights. The journalistic field is "the site of actions and reactions performed by social agents endowed with permanent dispositions, partly acquired in their experience of the social fields" (Bourdieu, 2005: 30), but the position of the field within the wider social formation of many interdependent fields has its state, national and cultural boundaries. In the institutional context of Serbian journalism, it is possible to be both idealistic and pragmatic because journalists are simultaneously saying what the role should be and what it really is. 
Journalistic culture in Serbia is seeking to find its articulation between two major influences of the last decades: the normative call to be watchdogs in the democratization process, and clientelist attitude fostered by local political culture and economic circumstances.

While the diversity of the cities we investigated implied the possibility that it be reflected on journalists' ethical attitudes, we found week evidence that the perception of the journalists' role in society is different in smaller and relatively homogenous towns than in larger and more demographically diverse cities. In line with the hierarchy of influences model that underlines the semiautonomous character of the journalistic field, this indicates that wider fields of influence with uniforming impact over-ride the articulation of local diversity in media. Journalistic culture in Serbia is formed in the environment of an oversaturated media market dependant on dwindling, state-controlled advertising (Savet za borbu protiv korupcije, 2015), rendering media highly vulnerable to influences on editorial policy, and with evident political influence by the governments and the political parties (Reljić, 2012).

Journalists' light preference for an interventionist role with a strong presence of a monitorial role and to some extent accommodative role, indicates 'multiculturalism' within a specific journalism culture. Following the community structure model, our detailed analysis of responses in three different cities and two regions shows that journalists in diverse communities (Belgrade and Subotica) more easily detach themselves from the reported, seeing their role as monitors of those in power, while those in more homogeneous societies (Kragujevac) tend to see journalist's role as an advocate for social change.

The size appears to matter for journalists in Kragujevac and Subotica, where influences of personal networks are stronger than in the capital Belgrade. In homogeneous Kragujevac, journalists are more prone to take into account religious considerations, and also to trust religious leaders.

In terms of ethical orientation, variation of responses - for example, altering photos in Belgrade is slightly more "acceptable" than changing quotes - requires more research before deciding if it relates more to demographic diversity of the city or the specifics of the media market, diversity of ownership models, media platforms, presence of tabloid press and similar. 


\section{References}

Andresen, K., Hoxha, A. \& Godole, J. (2017). New Roles for Media in the Western Balkans. Journalism Studies, 18(5): 614-628.

Bourdieu, P. (2005). The political field, the social science field, and the journalistic field. In Benson, R. \& Neveu, E. (eds.), Bourdieu and the journalistic field (pp. 29-48). Cambridge: Polity Press.

Cetinić, G. (2017). Mediji na nizbrdici. Novi Magazin, 322, 29-30, 29 July 2017.

Clifford, C. (1999). The Common Good as the First Principle. In Glasser, T. (ed.), The Idea of Public Journalism (pp. 67-84). New York: Guilford Press.

Dobek-Ostrowska, B. \& Glowacki, M. (eds.) (2008). Comparing Media Systems in Central Europe: Between Commercialization and Politicization. Wroclaw: University of Wroclaw Press.

Dunwoody, S. \& Griffin, R. (1993). Journalistic strategies for reporting longterm environmental issues: a case study of three superfund sites. In Hansen, A. (ed.), The mass media and environmental issues (pp. 25-50). Leicester: Leicester University Press.

Freedom House (2016). Freedom of the Press: Serbia. Accessed 30.06.2017. URL: https://freedomhouse.org/report/freedom-press/2016/serbia.

Glasser, T. L. (ed.). (1999). The Idea of Public Journalism. Guilford Press.

Hallin, D. \& Mancini, P. (2004). Comparing Media Systems: Three Models of Media and Politics. Cambridge: Cambridge University Press.

Hallin, D. (2005). Field theory, differentiation theory and comparative media research. In Benson, R. \& Neveu, E. (eds.), Bourdieu and the journalistic field (pp. 224-243). Cambridge: Polity.

Hanitzsch, T., Anikina, M., Berganza, R., Cangoz, I., Coman, M., Hamada, B., Hanusch, F., Karadjov, C.D., Mellado, C., Moreira, S.V. \& Mwesige, P.G. (2010). Modeling perceived influences on journalism: Evidence from a cross-national survey of journalists. Journalism \& Mass Communication Quarterly, 87(1): 5-22. 
Hanitzsch, T. \& Mellado, C. (2011). What Shapes the News around the World? How Journalists in 18 Countries Perceive Influences on Their Work. The International Journal of Press/Politics, 20(10): 1-23.

Hanitzsch, T., Hanusch, F. \& Lauerer, C. (2014). Setting the Agenda, Influencing Public Opinion, and Advocating for Social Change: Determinants of Journalistic Interventionism in 21 Countries. Journalism Studies, 17(1): $1-20$.

Media Sustainability Index (2017). IREX. Accessed 30.06.2017. URL: https:// www.irex.org/resource/media-sustainability-index-msi.

Jackman, R. \& Miller, R. (1996). A Renaissance of Political culture. American Journal of Political Science, 40(3): 632-659.

Jones, C. (1980). Mass Media Codes of Ethics and Councils: A comparative international study on professional standards. Paris: UNESCO.

Lauk, E. (2009). Reflections on Changing Patterns of Journalism in the New EU Countries. Journalism Studies, 10(1): 69-84.

Mancini, P. \& Zielonka, J. (2012) Introduction. The International Journal of Press/Politics, 17(4): 379-387.

Milivojević, S. (2012). Low wages and high technology: Journalists and journalism in Serbia. Kultura, 135: 285-298.

Örnebring, H. (2009). Comparative European Journalism: State of Current Research. Oxford: Reuters Institute for Study of Journalism. Working paper. Accessed 30.06.2017. URL: https://reutersinstitute.politics.ox.ac.uk/sites/ default/files/Comparative\%20European\%20Journalism_0.pdf.

Plaisance, P. L., Skewes, E. \& Hanitzsch, T. (2012). Ethical Orientations of Journalists around the Globe. Communication Research, 39(5): 641- 661

Popović-Obradović, O. (2007). The roots of anti-modern political culture in Serbia. Helsinki Committee for Human Rights in Serbia. Accessed 28.06.2017. URL: www.helsinki.org.rs/doc/Roots\%20of\%20anti\%20 modern.doc.

Press Council (2015). Serbian Journalists' Code of Ethics. Accessed 30.06.2017. URL: http://www.savetzastampu.rs/english/serbian-journalists-code-ofethics. 
Reljić, D. (2012). The West Balkans: Accessing the Union. Accessed 26.06.2017. URL: http://www.swp-berlin.org/en/publications/point-of-view/the-westbalkans-accessing-the-union.html.

Rupar, V. (2007). Investigating the journalistic field: The influence of objectivity as a journalistic norm on the public debate on genetic engineering in New Zealand (Doctoral dissertation, The University of Waikato).

Rupar, V. (2014). Journalism, environment and community structure: news and opinions in the coverage of the genetic engineering issue in New Zealand. MEDIANZ: Media Studies Journal of Aotearoa New Zealand, 12(1): $40-57$.

Savet za borbu protiv korupcije (2015). Izveštaj o mogućem uticaju institucija javnog sektora na medije kroz plaćanje usluga oglaśavanja i marketinga. Beograd: Savet za borbu protiv korupcije. Accessed 30.06.2017. URL: http:// www.antikorupcija-savet.gov.rs/Storage/Global/Documents/izvestaji/Izvestaj\%20o\%20medijima\%20konacna\%20verzija.pdf.

Shoemaker, P. \& Reese, S. (2014). Mediating the Message in the 21st Century (3rd Edition). New York: Routledge.

Stamenova, S. (2005). "Peculiarities of Balkan Political Culture and Interethnic Understanding: The cases of Macedonia, Serbia and Montenegro, and Bulgaria”. Paper presented at the annual meeting of the International Studies Association, Hilton Hawaiian Village, Honolulu, Hawaii, Mach 5, 2005.

Tichenor, J., Donohue A. \& Olien, N. (1980). Community conflict and the press. Beverly Hills CA: Sage.

Topf, R. (1989). Political Change and Political Culture in Britain, 1959-87. In Gibbins, J., Contemporary Political Culture: Politics in a Postmodern Age (pp. 52-81). London: Sage.

Worlds of Journalism Study (2017). Accessed on 12.06.2017. URL: http:// www.worldsofjournalism.org/. 
Ethics and professional orientation

Verica Rupar

of Serbian journalists

Sonja Seizova 